\title{
Bouleiceras (Hildoceratidae, Ammonitina) from the lower Toarcian (Jurassic) of the Iberian Range (Spain): Taxonomy, stratigraphic distribution and insights on its dispersal ${ }^{\text {is }}$
}

\author{
Gemma Martínez, Fernando García Joral* \\ Departamento de Geodinámica, Estratigrafía y Paleontología (GEODESPAL), Facultad de Ciencias Geológicas, Universidad Complutense de Madrid, Madrid, \\ Spain
}

\section{A R T I C L E I N F O}

\section{Article history:}

Received 26 July 2019

Accepted 14 July 2020

Available online $\mathrm{xxx}$

\section{Keywords:}

Bouleiceratinae

Biostratigraphy

Paleobiogeography

Lower Jurassic

Western Tethys

\begin{abstract}
A B S T R A C T
Bouleiceras is a very rare genus among the rich assemblages of ammonoids from the lower Toarcian of the Iberian Range. So far, only two dozen specimens have been recorded in numerous field campaigns carried out since 1965 by different authors. The interest of this taxon lies in its peculiar paleogeographical distribution in comparison with most other ammonoids of the same age. A review of these specimens is carried out, including those obtained in previous works and others recently collected in selected localities. Based mainly on the differences in the shape of the ventral section and the suture line, seven species have been identified; two of which are new: Bouleiceras ibericum nov. sp. and Bouleiceras? betetensis nov. sp. All the reviewed specimens are recorded in the Semicelatum Subzone of the Tenuicostatum Zone and the Elegantulum Subzone of the Serpentinum Zone from the Central Sector and the Levantine Sector of the Iberian Range. The global distribution of the genus is summarized from the known data, and its possible dispersal routes are analyzed, as well as the factors that could have conditioned them.
\end{abstract}

(c) 2020 Elsevier Masson SAS. All rights reserved.

\section{Introduction}

The genus Bouleiceras Thévenin, 1906 is an exotic member of some ammonoid assemblages of the Lower Jurassic of Western Tethys, whose presence does not seem to fit well with the provincialism established in the region during most of the Mesozoic. Until the 1950s, it was only known from Madagascar, where the type species Bouleiceras nitescens Thévenin, 1906, was described by Thévenin (1906, 1908), Collignon (1958), and Blaison (1968). Afterwards, this and other species assigned to Bouleiceras have been recognized in different basins of Northeast and Northwest Africa, Arabia, the Indian subcontinent, the Iberian Peninsula, and South America. In Arabia, Bouleiceras was recorded in several localities by Steinecke and Bramkamp (1952) and described by Arkell (1952) who defined several new species, as well as by Enay and Mangold (1994). All these records come from the Lower Marrat Fm., where they appear together with Protogrammoceras madagascariense (Thévenin) and Calyptoria sp.,

\footnotetext{
Corresponding editor: Claude Monnet.

* Corresponding author.

E-mail address: fgjoral@ucm.es (F. García Joral).
}

the same association found in Madagascar (Basse and Karpoff, 1957). In Northeast Africa it has been cited in Kenya (Ayers, 1952; Arkell, 1956) and in the Uanei Fm. in Somalia (Chiocchini et al., 2002). In Pakistan, B. nitescens and another species B. chakdallaense Fatmi, 1972, have been recorded (Davies and Gardezi, 1965; Fatmi, 1972; Fatmi and Hölder, 1975). Outside the Indo-Madagascan Area, Bouleiceras has been cited in the Western Tethys area in Portugal (Mouterde, 1953; Dubar and Mouterde, 1953; Mouterde and Rocha, 1981), in the Iberian Range in Spain (Geyer, 1965, 1971; Behmel and Geyer, 1966; Bizon et al., 1966; Dubar et al., 1970; Mouterde, 1970, 1971; Marin and Toulouse, 1972; Goy, 1974, 1975; Herrero-Organero, 1986; Goy et al., 1988; Herrero Matesanz, 1995; Goy and Martínez, 1996; Martínez, 2017a) and in the Pre-Rif of Morocco (Faugères, 1975). In addition, the genus has been recorded in Chile (Hillebrandt, 1973, 1984, 1987; Hillebrandt and Schmidt-Effing, 1981). The stratigraphic position of all these records has been considered in the interval between the upper Pliensbachian Spinatum Zone and the lower Toarcian Serpentinum Zone.

The aim of the present paper is to review the fossils attributed to Bouleiceras recorded in the Iberian Basin. For this purpose, its taxonomy has been updated and its stratigraphic distribution has been accurately established. The global stratigraphic distribution 
of the species of this genus is also discussed from the available data, as well as the possible factors that triggered its geographical dispersion.

\section{Studied material}

The Bouleiceratinae represent less than $3 \%$ of the Hildoceratidae and $1 \%$ of the total of the ammonoids recorded in the lower Toarcian of the Iberian Range. The studied specimens belonging to Bouleiceras have been collected during the realization of regional works and doctoral theses, between 1965 and 1996, by different authors (Comas-Rengifo, Fernández-Lopez, Goy, Herrero Matesanz, Herrero-Organero, Suárez Vega, and Meléndez) in the central sector of the Iberian Range (Fig. 1). Most of the specimens obtained in these works are currently deposited in the Paleontological collections of the Complutense University of Madrid, including the specimens identified as B. cf. tumidum Arkell, 1952, and B. nitescens Thévenin, collected by Mouterde (1971: p. 349) in Obón (Teruel). Specimens collected by Herrero-Organero and Suárez-Vega in Moneva (Zaragoza) and deposited in the Jurassic Museum of Asturias (MUJA) have been also reviewed, and the specimens figured by Geyer (1965: pp. 27, 28, pl. 5, figs. 1-3) as B. arabicum Arkell, 1952, B. marraticum Arkell, 1952, and B. cf. elegans Arkell, 1952 from Albarracín (Teruel), as well as B. nitescens figured by Bizon et al. (1966: p. 902, pl. 27a, fig. 7a-c) from Tavernes de la Valldigna (Valencia), in the Levantine Sector of the Iberian Range, have also been considered in the revision. Besides this, new specimens have been collected during the last years in the sections of Ariño (Teruel), Moneva (Teruel), Turmiel (Guadalajara), and Valsalobre de Beteta (Cuenca). Some isolated or "ex situ" specimens have also been collected in Albarracín (Teruel), Entrambasaguas (Teruel), Ribarredonda (Guadalajara), Ablanquejo (Guadalajara), Calanda (Teruel), and Barahona (Soria).

\section{Stratigraphic framework}

All the specimens come from the Turmiel Fm. (Goy et al., 1976). This formation is composed by the alternation of marls and mudstone carbonates, which are organized into sets of deepening and shallowing-upwards sequences (Gómez and Goy, 2000).
Sequentially, the sedimentation of this unit started with a generalized transgressive event during the early part of the Tenuicostatum Zone that reached its maximum deepening at the middle part of the Bifrons Zone. Nevertheless, the transgression is not represented by a continuous simple deepening episode, but by several pulses (Gómez and Goy, 2000, 2005). There are two cycles and the transgressive maximum of the first one is at the Elegantulum Subzone, resulting in the establishment of external platform environments facilitating the transport of ammonite shells by drift into most of the area of our studies.

Most of the Bouleiceras specimens recorded in the Iberian Range come from the interval between the Semicelatum Subzone of the Tenuicostatum Zone and the Elegantulum Subzone of the Serpentinum Zone. The biostratigraphic scheme used in this work follows Goy et al. (1988) and the standard chronostratigraphic reference scales for the Toarcian proposed by Elmi et al. (1997) and Page (2003). The succession of biohorizons (Figs. 2,3) corresponds to the regional data derived from Comas-Rengifo (1982) for the Pliensbachian and from Goy et al. (1988), Goy and Martínez, 1990Goy and Martínez (1990), Comas-Rengifo et al. (2010), as well as unpublished data, for the lower Toarcian. Figs. 2 and 3 show the precise stratigraphic position of the Bouleiceras species collected in the referenced sections.

\section{Systematic paleontology (G. Martínez)}

Order Ammonitida Fischer, 1882

Suborder Ammonitina Fischer, 1882

Superfamily Hildoceratoidea Hyatt, 1867

Family Hildoceratidae Hyatt, 1867

Subfamily Bouleiceratinae Arkell, 1950

Genus Bouleiceras Thévenin, 1906

Type species: Bouleiceras nitescens Thévenin, 1906. Lectotype in Thévenin (1908: pl. 2, fig. 6a, b), coming from Bekoratsaky, Maevatanana, Madagascar.

Other included species: $B$. tumidum Arkell, 1952; B. arabicum Arkell, 1952; B. marraticum Arkell, 1952; B. elegans Arkell, 1952; B. rectum Arkell, 1952; B. chakdallaense Fatmi, 1972; B. chilense Hillebrandt 1973; B. ibericum nov. sp.; Bouleiceras? betetensis nov. sp.

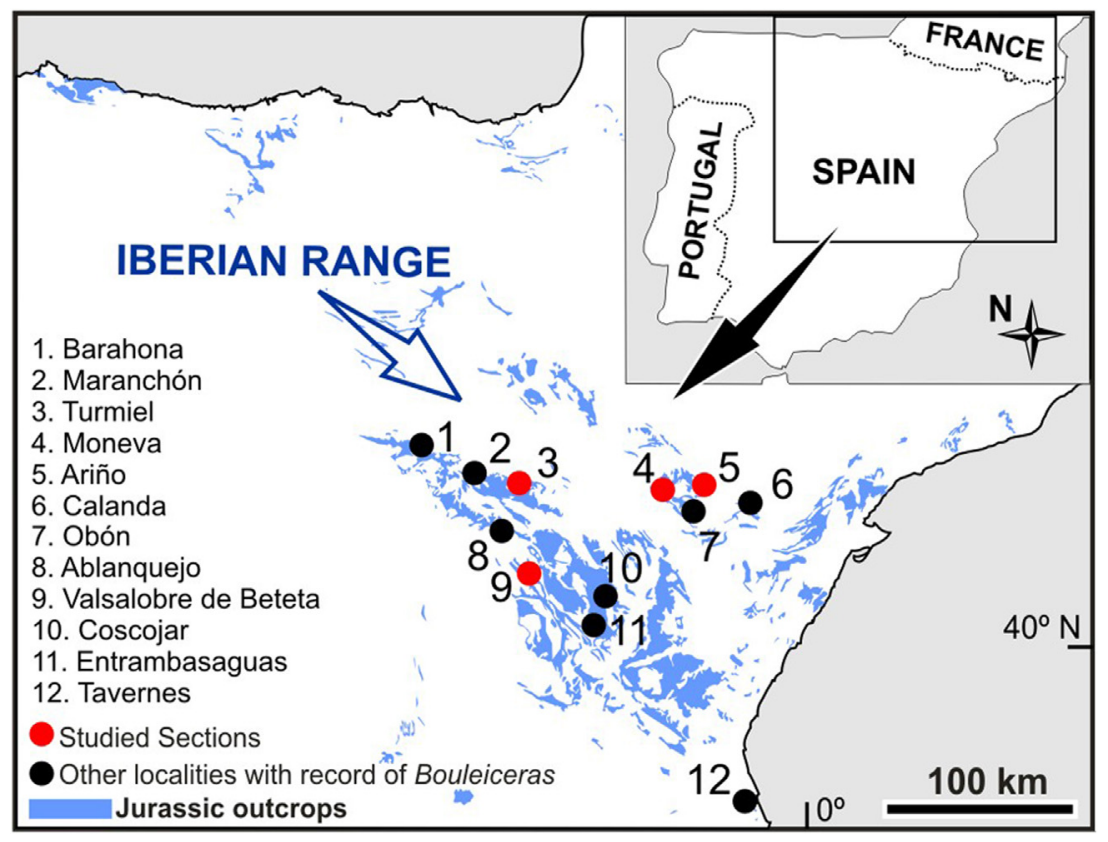

Fig. 1. Geographical location of the lower Toarcian sections mentioned in the text. 


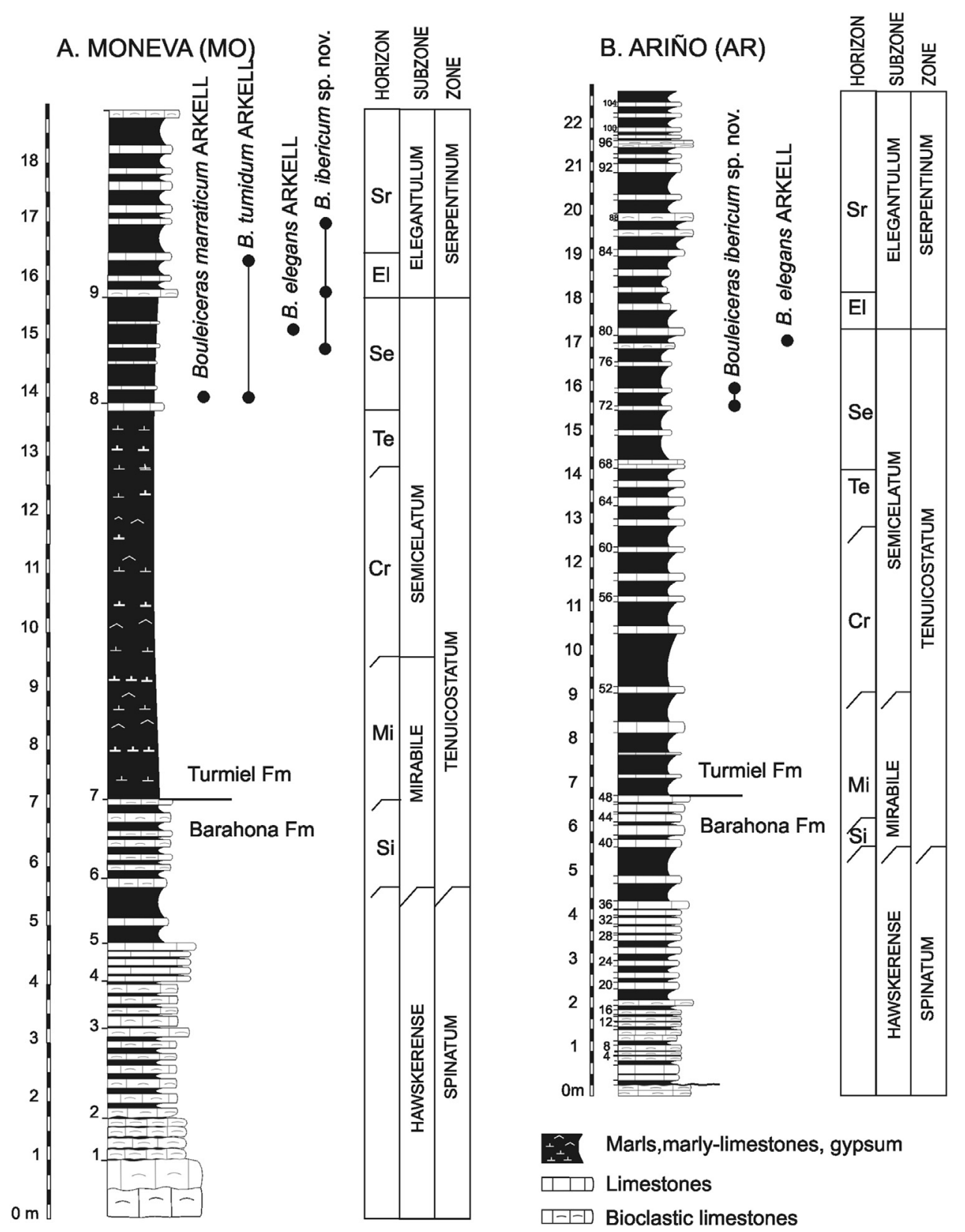

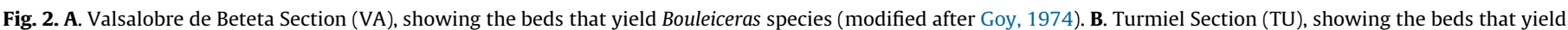

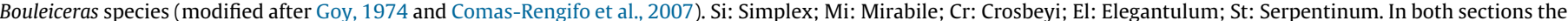
boundary between the Barahona and Turmiel formations is indicated.

Remarks: According to the diagnosis given by Howarth (2013: p. 81), this genus is:"evolute, coronate inner whorls, becoming more involute, planulate, and compressed on outer whorls; strong ventral keel throughout; innermost whorls are smooth, followed by a uni- or bituberculate stage, with or without ribs, then a stage with strongly rursiradiate, straight or sinuous ribs that bifurcate from umbilical tubercles, and finally a flat-sided smooth adult stage; sutures ceratitic, with wide entire saddles, and a deep digitate first lateral lobe".

Bouleiceras nitescens Thévenin, 1906

Fig. 4(A-D)

1906. Bouleicera nitescens n. sp. - Thévenin, p. 171, figs. 1-3. 1908. Bouleiceras nitescens Thévenin - Thévenin, p. 13, pl.2, figs. 6 (lectotype), 7 and 11 ?
1910. Bouleiceras nitescens - Haug, p. 995, fig. 308.

1952. Bouleiceras nitescens Thévenin - Arkell, p. 261, pl. 15, figs. 5a, b; text- fig. 4.

1953. Bouleiceras cf. nitescens Thévenin - Mouterde, p. 7, pl. 1, fig. $1 \mathrm{a}, \mathrm{b}$.

1958. Bouleiceras nitescens Thévenin - Collignon, pl. 1, figs. 1-3. 1966. Bouleiceras nitescens Thévenin - Bizon et al., pl. 27a, fig. 7a-c. 1971. Bouleiceras nitescens Thévenin - Mouterde, p. 349.

1974. Bouleiceras nitescens Thévenin - Goy, p. 570, pl. 40, fig. 2 a-c. 1974. Bouleiceras cf. nitescens Thévenin - Comas-Rengifo, p.129, pl. 14, fig. 2a, b.

?1981. Bouleiceras nitescens? Thévenin - Mouterde and Rocha, p. 219, pl. 2, fig. 2a, 2b.

Material: Specimens Ab-11/1; Tu-10.2/3; 2Eb-10.28/1; Ob-14B/1. All specimens are incomplete phragmocones. 


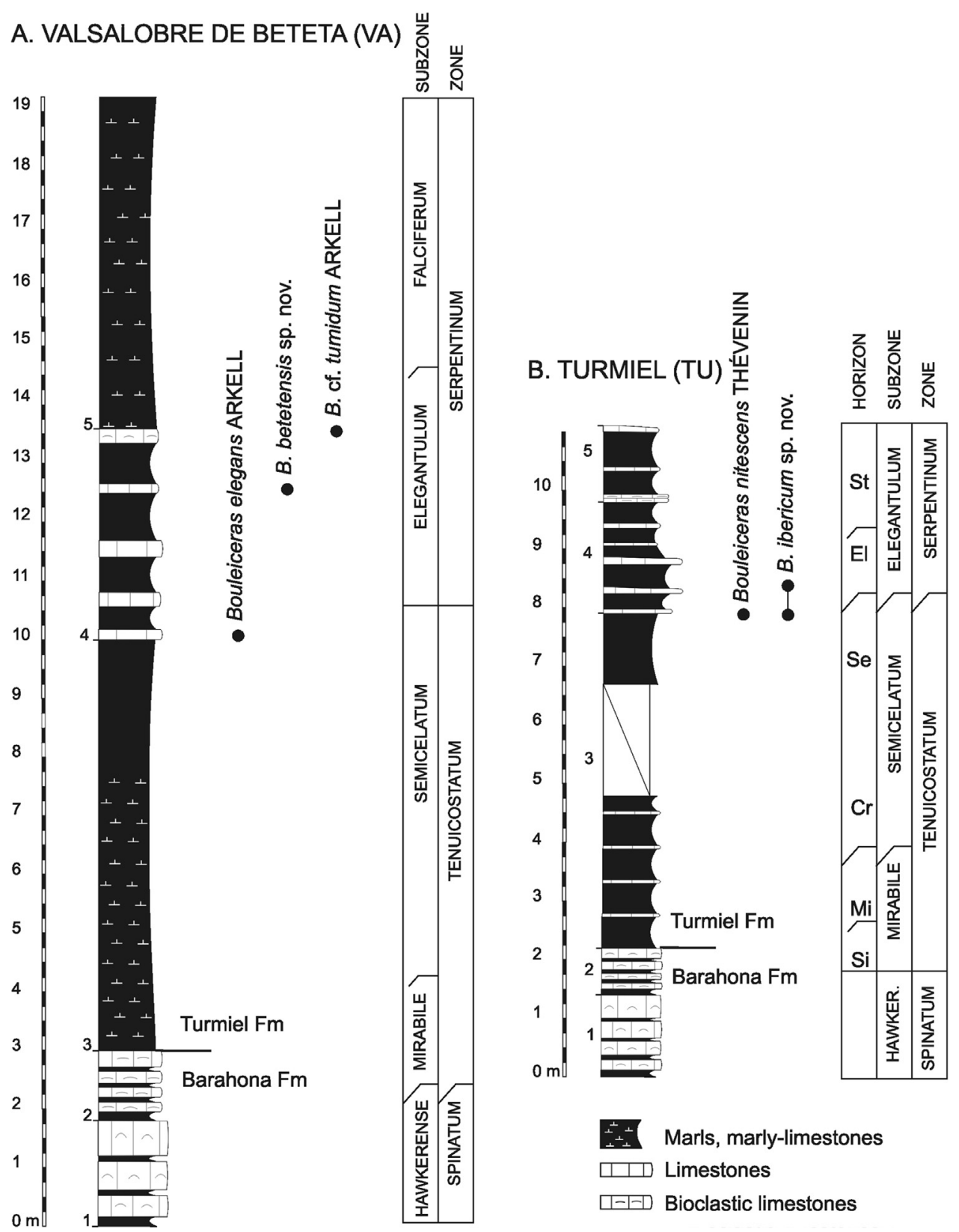

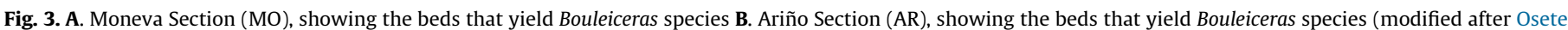

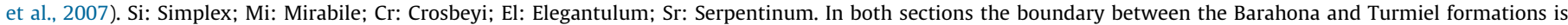
indicated.

Geographic and stratigraphic distribution: In the Iberian Range, this species has been recorded in the uppermost Semicelatum Subzone of the Tenuicostatum Zone in Turmiel, and in the Elegantulum Subzone of the Serpentinum Zone in Ablanquejo, Entrambasaguas and Obón. In Tavernes de la Valldigna, this species comes from Bizon et al.'s (1966) level 7 (6 m thick), associated with the brachiopods Dispiriferina? oxyptera (Buvignier, 1843), Lobothyris arcta (Dubar, 1931) and Aulacothyris iberica Dubar, 1931, species that in the Iberian Range only coexist in the Semicelatum Subzone of the Tenuicostatum Zone (García Joral and Goy, 2000; Baeza-Carratalá et al., 2016).

Measurements: see Table 1.

Description: Shell moderately evolute, whorl expansion rate (WER) between 1.81 and 1.96; subtrapezoidal compressed section, with maximum width close to the umbilicus and flat flanks. The ventral region presents a keel bordered by two shallow furrows.
The umbilical area is relatively wide, with convex rounded edges. The ornamentation is marked in the first whorls, becoming more tenuous until disappearing in advanced stages; in internal whorls it is composed of rounded and spaced tubercles from which arise pairs of straight and retroverse ribs, somewhat finer than the intercostal spaces, protruding slightly before disappearing near the ventral region. Suture line with external saddle (ES) and external lobe (EL) narrow and deep; first lateral saddle (LS1) wide, smooth and divided by a narrow and short central lobe; LL1 somewhat smaller than LS1 with several sharp cuts in the posterior region and semi-parallel and smooth flanks; LS2 approximately equal in width than the LS1, smooth and rounded; LL2 narrow and sharp. In the umbilical edge, rounded saddles and acute lobes, all of small size, are observed as accessory elements.

Remarks: $B$. nitescens differs from $B$. elegans by its less evolute and compressed shell, more tuberculated in the phragmocone. It 

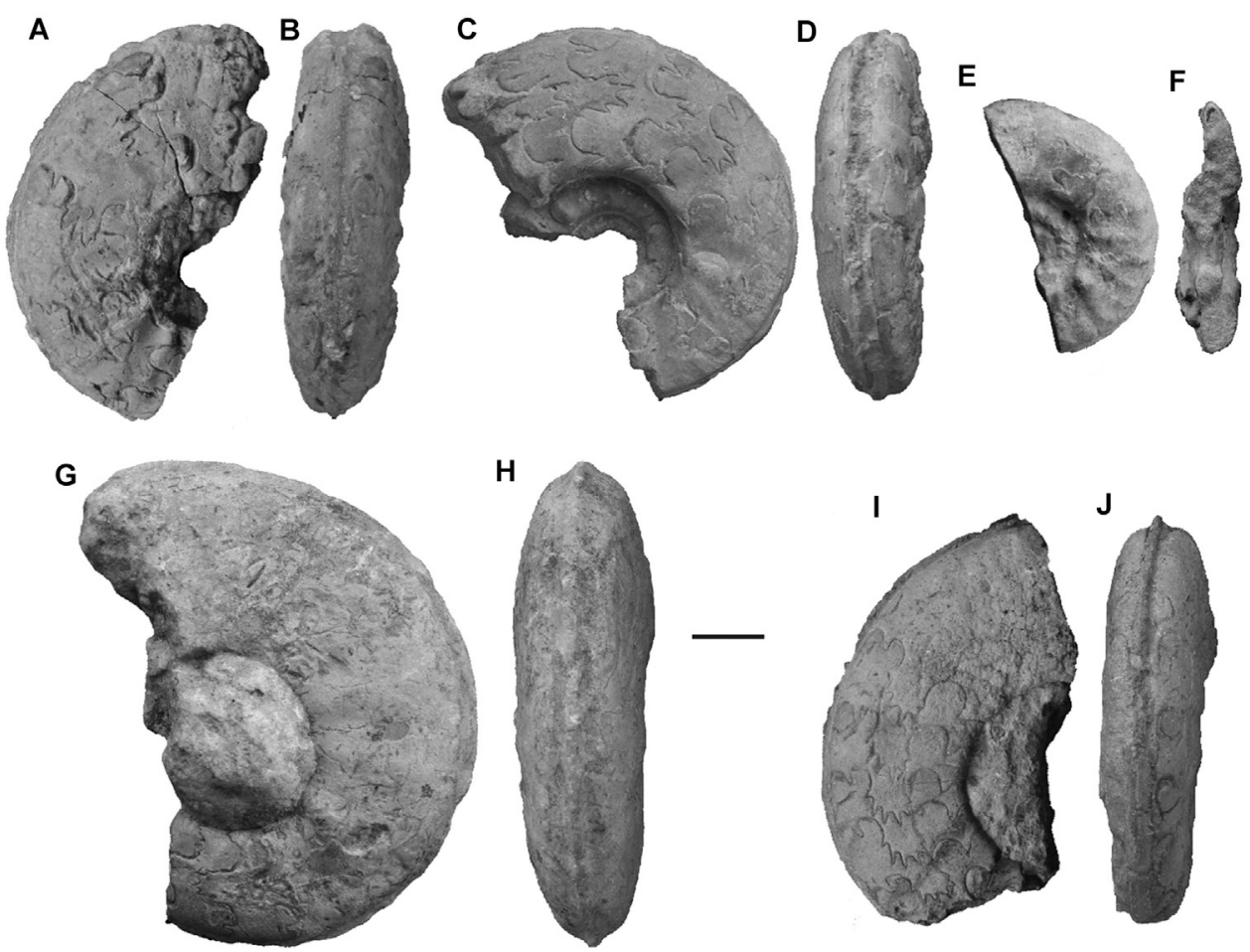

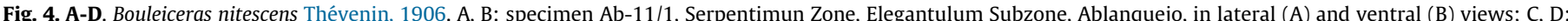

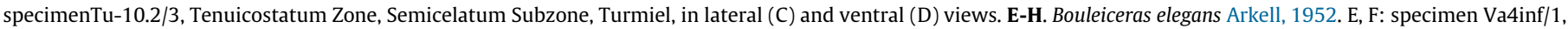

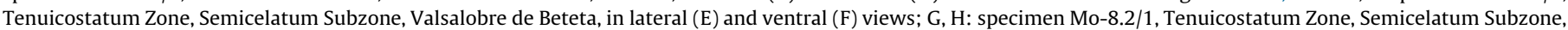

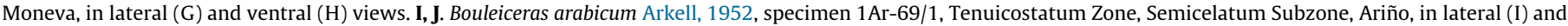
ventral $(\mathrm{J})$ views. Scale bar: $1 \mathrm{~cm}$.

Table 1

Measurements of the studied specimens of Bouleiceras. D: shell diameter; H: last whorl high; h: H/D; W: last whorl width; w: W/D; U: Umbilicus diameter; u: U/D; WER: whorl expansion rate: $\mathrm{M}=$ moderate; $\mathrm{H}=$ high (see Korn, 2010).

\begin{tabular}{|c|c|c|c|c|c|c|c|c|}
\hline Specimen & $\mathrm{D}$ & $\mathrm{H}$ & $\mathrm{h}$ & W & w & $\mathrm{U}$ & $\mathrm{u}$ & WER \\
\hline \multicolumn{9}{|c|}{ B. nitescens Thévenin, 1906} \\
\hline $\mathrm{Ab}-11 / 1$ & 59.8 & 24.7 & 0.41 & 19.8 & 0.33 & 21.2 & 0.35 & $1.81 \mathrm{M}$ \\
\hline \multirow[t]{2}{*}{ Tu-10.2/3 } & 56.3 & 22.5 & 0.4 & 17.1 & 0.3 & 20.4 & 0.36 & - \\
\hline & 58.2 & 23 & 0.39 & 17.2 & 0.29 & 19.8 & 0.34 & $1.96 \mathrm{M}$ \\
\hline Ob-14B/1 & 67.3 & 26.9 & 0.4 & 19.3 & 0.29 & 24.2 & 0.36 & $1.89 \mathrm{M}$ \\
\hline \multicolumn{9}{|c|}{ B. elegans Arkell, 1952} \\
\hline Mo-8.2/1 & 72.2 & 30.2 & 0.42 & 22.2 & 0.31 & 24.9 & 0.34 & $2.02 \mathrm{H}$ \\
\hline $1 \mathrm{Ar}-76 / 1$ & 120 & 47.3 & 0.39 & 30.7 & 0.23 & 49.4 & 0.4 & $2.14 \mathrm{H}$ \\
\hline \multicolumn{9}{|c|}{ B. marraticum Arkell, 1952} \\
\hline Mo-7.20/2 & 22.4 & 8.9 & 0.39 & 8.2 & 0.36 & 9.7 & 0.43 & $1.96 \mathrm{M}$ \\
\hline \multicolumn{9}{|c|}{ Bouleiceras ibericum nov. sp. } \\
\hline Tu-10.2/2 & 20.2 & 8.2 & 0.41 & 6.3 & 0.31 & 6.6 & 0.32 & $1.79 \mathrm{M}$ \\
\hline
\end{tabular}

differs from $B$. ibericum nov. sp. in having a subtrapezoidal compressed section, tubercles in the inner whorls and the suture line more indented.

Bouleiceras elegans Arkell, 1952

Fig. 4(E-H)

1908. Bouleiceras nitescens - Thévenin, pl. 2, fig. 8 (holotype), 10. 1952. Bouleiceras elegans n. sp. - Arkell, p. 264, pl. 15, figs. $9,11 \mathrm{a}, \mathrm{b}$.

1958. Bouleiceras elegans Arkell - Collignon, pl. 1, figs. 5, 6.

?1958. Bouleiceras rochi nov. sp. - Collignon, pl. 3, fig. 22.

non 1965. Bouleiceras cf. elegans Arkell - Geyer, p. 28, pl. 5, fig. 2, text. fig. 1c.

1974. Bouleiceras cf. elegans Arkell - Goy, p. 569, pl. 40, fig. 3. 1986. Bouleiceras sp. - Herrero-Organero, p. 71, pl. 11, fig. 4. 1995. Bouleiceras sp. - Herrero Matesanz, p. 322.
Material: Specimens Mo-8.2/1, $1 \mathrm{Ar}-76 / 1$ (incomplete phragmocones and part of the body chamber) and $\mathrm{Cl}-22 / 1$, Va- 4 in./1 (incomplete phragmocones).

Geographic and stratigraphic distribution: In the Iberian Range, this species has been recorded in the Semicelatum Subzone of the Tenuicostatum Zone of Valsalobre de Beteta, Moneva, Ariño and Calanda.

Measurements: see Table 1.

Description: Shell evolute, WER index between 2.02 and 2.14; subovoidal compressed section in the inner whorls, more flattened in the external one, with maximum width close to the umbilicus. The ventral region presents a high and thick keel bordered by two shallow furrows. Wide umbilical area, with rounded edges and flat vertical walls. The ornamentation is progressively more tenuous during the ontogenetic development, until disappearing in the body chamber. In the inner whorls it is composed of small and rounded tubercles close to the umbilical edge, from which single or double retroverse ribs arise, somewhat finer than the intercostal spaces, protruding slightly near the ventral region. In 1 Ar76/1, two rows of tubercles joined by ribs are observed in the inner whorls. In the visible part of the suture line, EL is deep, narrow and acute, with the first lateral saddle (LS1) wide, smooth and divided by a narrow and short central lobe; the LL1 is somewhat smaller than LS1, trapezoidal with several sharp incisions; LS2 is rounded.

Remarks: $B$. elegans differs from $B$. nitescens by being more evolute and compressed, with weaker tubercles in the phragmocone.

Bouleiceras arabicum Arkell, 1952

Fig. 4(I, J)

1952. Bouleiceras arabicum n. sp. - Arkell, p. 262, pl. 15, figs. $6,8,13,14$ (holotype).

?1958. Bouleiceras arabicum Arkell - Collignon, pl. 2, figs. $9,10,13,14$, pl. 3, fig. 21 . 
1965. Bouleiceras arabicum Arkell - Geyer, p. 27, pl. 5, fig. 1, text. fig. $1 \mathrm{a}$.

?1975. Bouleiceras aff. arabicum Arkell - Faugères, p. 120, pl. 1, figs. 1a, b, 2a-c.

Material: Specimen 1Ar-69/1 (incomplete phragmocone and part of body chamber).

Geographic and stratigraphic distribution: The only specimen recorded in the Iberian Range comes from the Semicelatum Subzone of the Tenuicostatum Zone of Ariño.

Description: Shell evolute, the last whorl covering $1 / 3$ of the previous one; compressed section with flat flanks, almost parallels but slightly convergent in the ventral area. Thin and high keel bordered by two flat bands. Wide umbilical area, with rounded edges and flat and strongly inclined walls. The ornamentation is composed by low retroverse ribs which arise in pairs from a slight thickening close to the umbilical border and disappear near the ventral region. In the visible part of the suture line, EL is thin and deep, LS1 does not show cuts and is divided by a short and acute lobe; LL1 is somewhat smaller than LS1, with semi parallel sides and several sharp cuts posteriorly; LS2 is smooth and rounded, smaller than LL1.

Remarks: The last whorls are similar in this species to those of B. elegans, although with the flanks flatter and almost parallel. According to Arkell (1952), the ventral area is tabulated in the inner whorls.

Bouleiceras tumidum Arkell, 1952

Fig. 5(A-F)

1908. Bouleiceras nitescens Thévenin - Thévenin, pl. 2, fig. 9 (holotype).

1952. Bouleiceras tumidum n. sp. - Arkell, p. 261.

?1965. Bouleiceras cf. elegans Arkell - Geyer, p. 28, pl. 5, fig. 2, text. fig. 1c.

1970. Bouleiceras cf. tumidum Arkell - Mouterde, p. 349.
Material: Specimens Mo-7.20/1, Mo-5.1-2/4, Ob-14/1, Va-5.12/1 (incomplete phragmocones).

Geographic and stratigraphic distribution: The collected specimens come from the Semicelatum Subzone of the Tenuicostatum Zone and the Elegantulum Subzone of the Serpentinum Zone of Moneva. The specimen identified by Mouterde (1970, 1971) comes from the Elegantulum Subzone of Obón.

Description: Shells slightly evolute, the last exposed whorl covering half of the previous one; sub-trapezoidal to subrectangular compressed whorl-section, with gently convex flanks and maximum width in the umbilical edge. The ventral area presents a keel bordered by two shallow and narrow grooves disappearing in the outermost whorls, making the keel thicker. Umbilicus wide, with rounded edges and convex walls. The ornamentation is composed by thick and low retroverse ribs, slightly wider than the intercostal spaces, arising from a slight thickening in the umbilical edge and disappearing before reaching the ventral region. This ornamentation is not present in the more adult specimen. In the visible part of the suture line, EL is deep, LS1 wide, without incisions, and divided by a short lobe not centered; LL1 is somewhat smaller than LS1 and slightly wider in its posterior part, with semi-parallel sides and several sharp incisions posteriorly; LS2 smooth and rounded, wider than LL1; LL2 is similar to LS2 but half its size and with two acute incisions in the posterior part.

Remarks: $B$. tumidum is more involute and present a more inflated section than $B$. nitescens. In the holotype, the tubercles in the inner whorls are stronger. The specimen labeled Va-5.1-2/1 (Fig. 5(E, F)) has been included with doubts in this species, because the suture line presents numerous small and rounded incisions in the saddles. It comes from the uppermost levels of the species distribution (Strangewaysi Horizon).

Bouleiceras marraticum Arkell, 1952

Fig. 5(G, H)
A
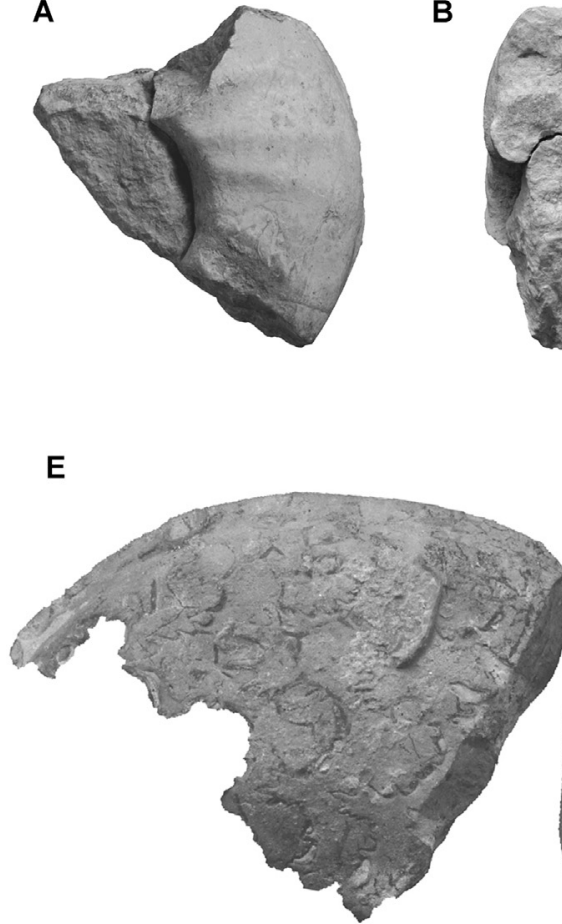

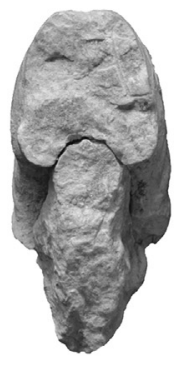

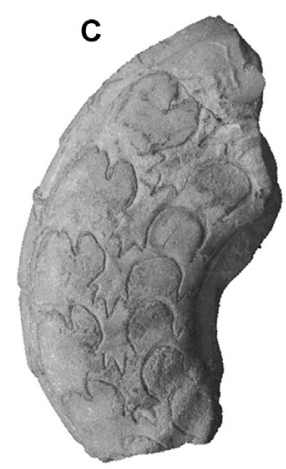

$\mathbf{F}$

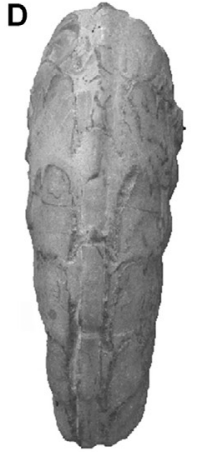

H
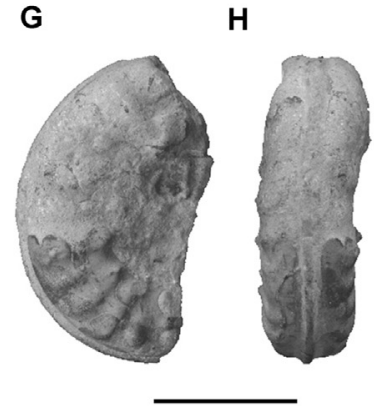

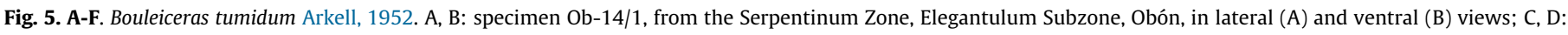

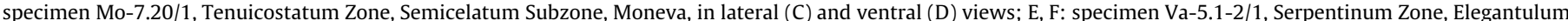

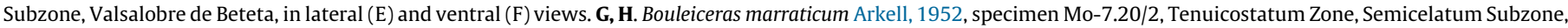
Moneva, in lateral $(G)$ and ventral $(H)$ views. Scale bars: $1 \mathrm{~cm}$. 
?1908. Bouleiceras nitescens Thévenin - p. 117, pl. 2, fig. 13.

1952. Bouleiceras marraticum n. sp. - Arkell, p. 263, pl. 15, fig. 10a-c (holotype).

1958. Bouleicerras marraticum Arkell - Collignon, pl. 2, fig. 12.

1965. Bouleiceras marraticum Arkell - Geyer, p. 58, pl. 5, fig. 3, text. fig. $1 \mathrm{~b}, 1 \mathrm{~d}$.

Material: Specimen Mo-7.20/2 (incomplete phragmocone).

Geographic and stratigraphic distribution: The only specimen recorded in the Iberian Range comes from the Tenuicostatum Zone, Semicelatum Subzone of Moneva.

Measurements: see Table 1.

Description: Shell moderately evolute, WER index of 1.96; subquadrangular to slightly sub-rectangular section, with almost flat and parallel flanks. Ventral region crossed by a thick keel bordered by two thin and shallow furrows. Wide umbilical region showing rounded edges and convex walls. Ornamentation composed of small marked tubercles on the umbilical edge from which arise pairs of broad and strong ribs, approximately equal in size to the intercostal spaces, very slightly retroverse and projected forward upon reaching the ventral region. The visible part of the suture line shows LS1 smooth and divided by a relatively thick central lobe, LL1 sharp and half the size of the anterior saddle and SL2 rounded and smooth.

Remarks: The specimen identified is probably a juvenile. It differs from B. arabicum by the more inflated internal whorls, the strong and sparse ribs and the more numerous tubercles.

Bouleiceras ibericum nov. sp.

Figs. 6, 7

1908. Bouleiceras nitescens -Thévenin, pl. 2, fig. 11.

?1952. Bouleiceras nitescens Thévenin - Arkell, text. fig. 4.

1974. Bouleiceras n. sp. - Goy, p. 571, pl. 39, fig. 1a-c.

1974. Bouleiceras sp. - Goy, p. 571, pl. 40, figs. 1a-c.

1974. Bouleiceras sp. - Comas-Rengifo, p. 129, pl. 14, fig. 1a, b.

1986. Bouleiceras sp. - Herrero-Organero, pl. 11, fig. 5.

Derivation of the name: From the Iberian Cordillera, where it is the most frequent form of Bouleiceras.

Holotype: Specimen Tu10.2/1 (Fig. 6(C, D)) coming from a level located at the extreme base of the Elegantulum Subzone of the Turmiel Section. It is housed in the Paleontological collection of the

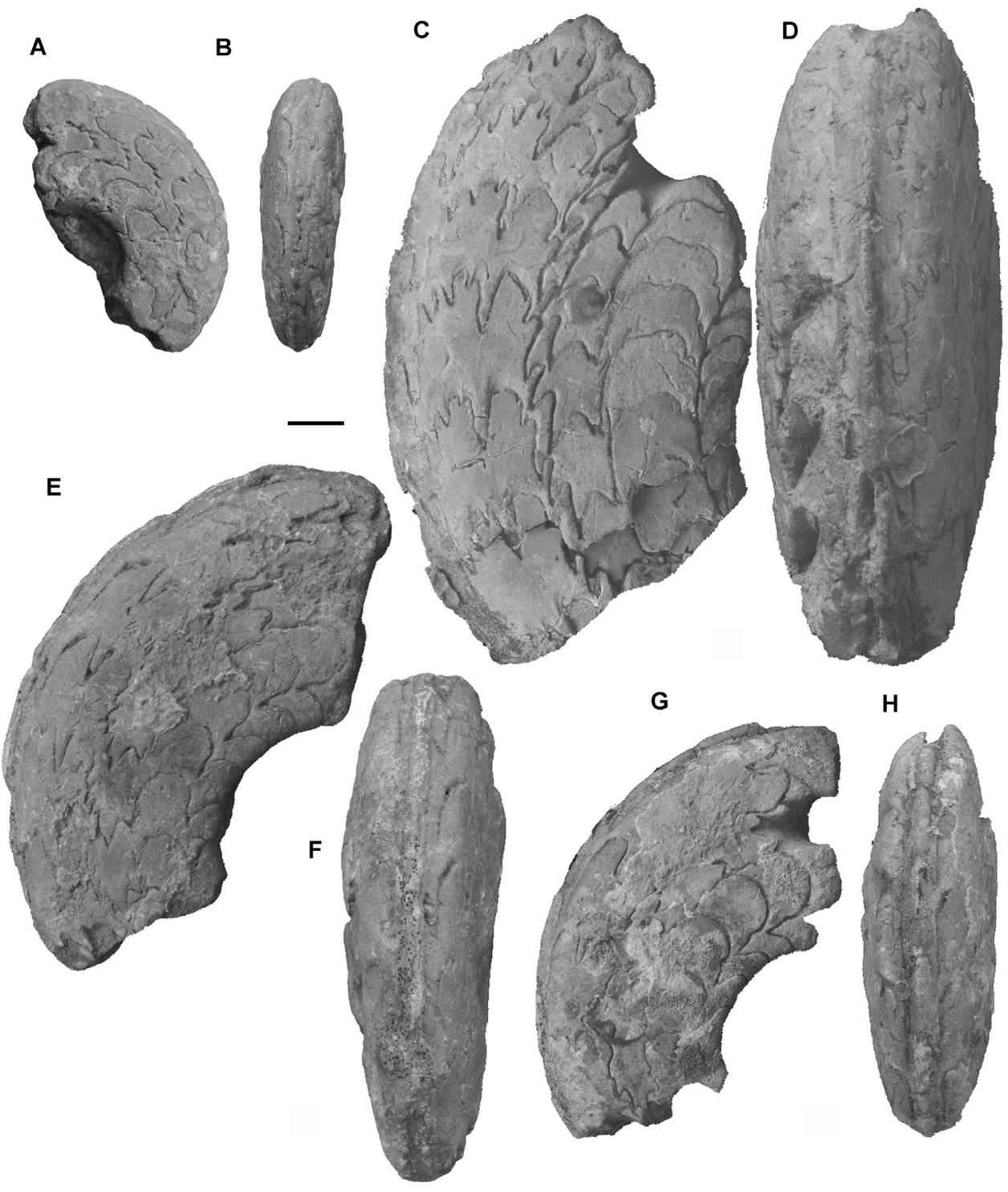

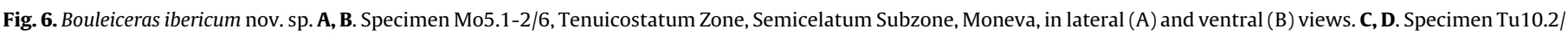

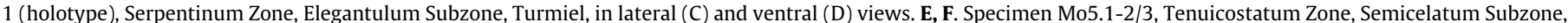

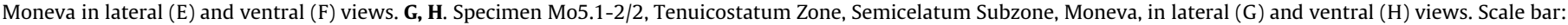
$1 \mathrm{~cm}$. 
G. Martínez, F. García Joral/Geobios xxx (2020) xxx-xxx

Complutense University of Madrid (Department of Geodynamics, Stratigraphy and Paleontology).

Material: Specimens Bh-5.2/1; Tu-10.2/1; Tu-10.2/2; Ab-11/2; Mo-5.1-2/1,2,3,5,6; $1 \mathrm{Ar}-72 / 1$ (2Ar-8/1); $\mathrm{Ar}-74 / 1$ (2Ar-8/2). All of them are incomplete phragmocones.

Geographic and stratigraphic distribution: This species has been recorded in the uppermost Semicelatum Subzone of the Tenuicostatum Zone in Turmiel, Moneva and Ariño, and in the Elegantulum Subzone of the Serpentinum Zone in Barahona, Turmiel, Ablanquejo and Moneva.

Measurements: see Table 1.

Diagnosis: Shell smooth, moderately evolute. Suboval compressed section, with marked keel, bisulcate in the inner whorls. Ceratitic suture with wide saddles and deep lobes.

Description: Shell moderately evolute (WER index: 1.79 in the only adult specimen measurable); suboval compressed section with gently convex flanks, showing the maximum width near the umbilical region and converging towards the ventral region; marked and raised keel bordered by two bands slightly sunken in the first whorls, but disappearing in the later whorls. Umbilical area with rounded edge and smooth walls, vertical in inner whorls and strongly convex in later stages. The suture line presents EL1 very deep and narrow, LS1 broad, divided by a central lobe, sometimes with small acute incisions in its ventral half; LL1 narrow with semi-parallel sides, somewhat wider and with several sharp incisions on its posterior part, LS2 rounded and smooth, slightly wider than the anterior lobe, LL1 acute and of small size. Acute lobes and rounded wide chairs appear as accessory elements on the umbilical edge and walls.

Remarks: This new species is morphologically close to $B$. nitescens, differing by its sub-oval section, absence of ornamentation on internal whorls, and a more indented suture line, especially in LL2, which has more irregularly distributed incisions. As for the WER index, the only adult specimen that could be measured has a moderate value, lower than that of $B$. nitescens. The main differences with other described species of the genus are as follows: B. elegans is more evolute and with a more compressed section. B. arabicum is also more evolute and with a more compressed section, showing a more indented LS1. B. tumidum is more involute, with a more globose (even sub-trapezoidal) section. B. marraticum have a different, subquadrangular section, and prominent ornamentation.? B. betetensis nov. sp. is also more involute, with a more compressed and sharpened section and a less indented suture line.

?Bouleiceras betetensis nov. sp.

Fig. 8

Derivation of the name: Referred to the locality of Valsalobre de Beteta (Cuenca).

Holotype: Specimen Va-5.2/3 (Fig. 8(D, E)) coming from the Serpentinum Zone, Elegantulum Subzone, of Valsalobre de Beteta. It is housed in the Paleontological collection of the Complutense University of Madrid (Department of Geodynamics, Stratigraphy and Paleontology).

Material: Two incomplete phragmocones: 1Eb-5.2/1 (paratype; Fig. 8(A-C)) and Va-5.2/3.

Geographic and stratigraphic distribution: This species has been recorded only in the Serpentinum Zone, Elegantulum Subzone, of Entrambasaguas and Valsalobre de Beteta.

Diagnosis: Shell smooth, involute. Subtriangular section, strongly compressed. Elevated keel. Ceratitic suture.

Description: Shell moderately involute. Subtriangular compressed section, the last visible whorl covering half of the previous one. No ornamentation is observed. The ventral region is rounded, with a thin and elevated keel. The umbilicus presents marked edges, somewhat rounded, and flat and very vertical walls. EL1 deep and acutely sharpened; ES1 wide, without incisions and divided by a narrow and acute central lobe that reaches a depth of almost the middle of the saddle; LL1 narrower than the previous saddle, with several sharp incisions in the posterior part and the sides smooth and semi-parallel, LS2 larger than the anterior lobe, rounded, deep and smooth. The following lobes are small but sharp and the saddles wide and rounded until reaching the umbilical wall.

Remarks: The suture line of this species is consistent with that of Bouleiceras, although both saddles and lobes are slightly less indented. However, the specimens studied show no ornamentation, their umbilicus is smaller, and the sections are clearly subtriangular. This combination of characteristics makes it possible to differentiate this species from any other species of this genus (Fig. 9), being more similar to what is observed in species of Nejdia Arkell, 1952 such as $N$.
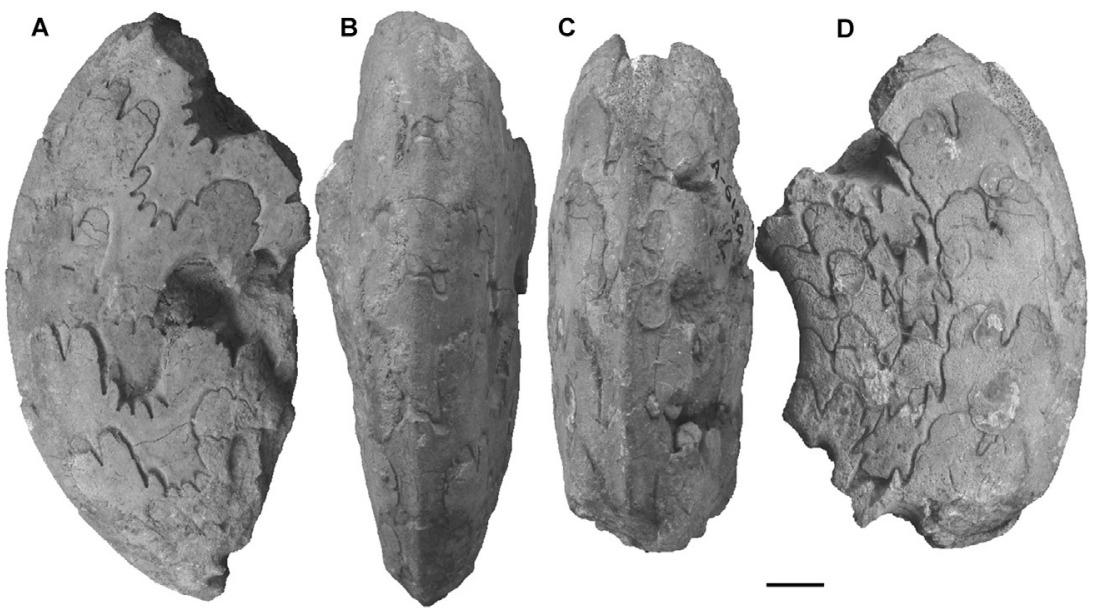

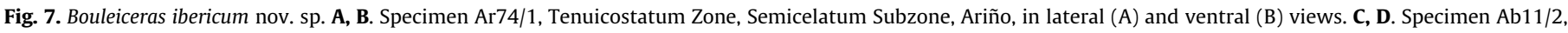
Serpentinum Zone, Elegantulum Subzone, Ablanquejo, in ventral (C) and lateral (D) views. Scale bar: $1 \mathrm{~cm}$. 

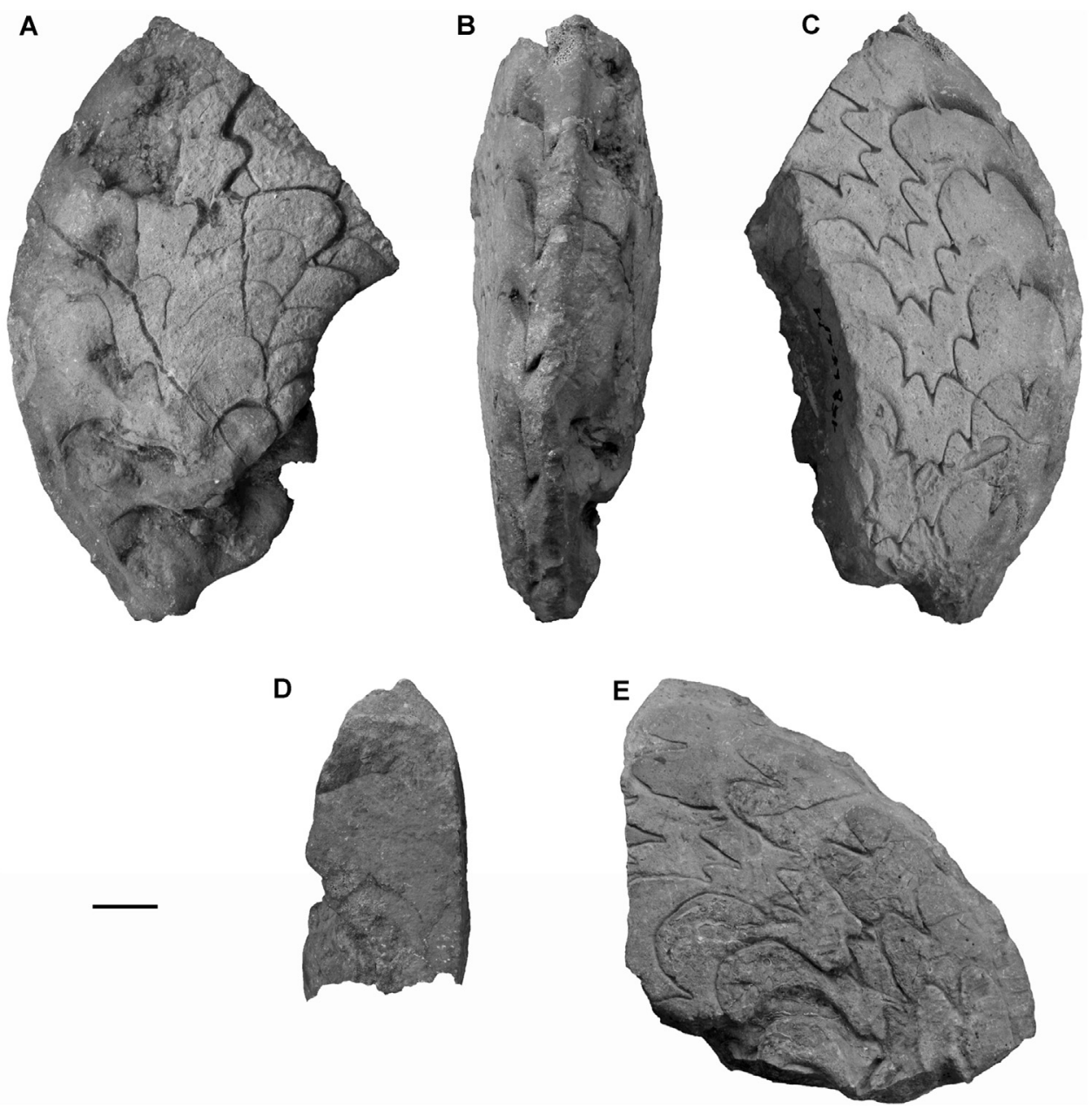

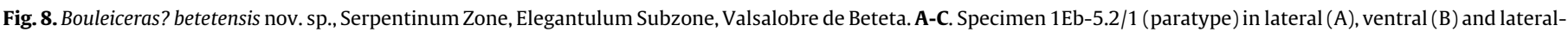
opposite (C) views. D, E. Specimen Va-5.2/3 (holotype) in ventral (D) and lateral (E) views. Scale bar: $1 \mathrm{~cm}$.

bramkampi Arkell, 1952 or N. pseudogruneri (Thévenin, 1908). For this reason, the generic determination of? B. betetensis nov. sp. is uncertain and a question mark has been placed related to the generic name. It is worth remembering that, according to Guex (1974), Nejdia appears to be phylogenetically related to Bouleiceras, and both $N$. bramkampi and N. pseudogruneri have been recorded in the Serpentinum Zone of the Iberian Range (Goy and Martínez, 1996).

\section{Discussion}

Stratigraphic distribution of the Bouleiceras species

In the Iberian Basin, the oldest species of Bouleiceras is $B$. elegans, recorded from the middle part of the Semicelatum Subzone (Herrero Matesanz, 1995), possibly from the Tenuicostatum biohorizon. Immediately above, in the Semicelatum Subzone, Semicelatum biohorizon, B. arabicum and B. marraticum have been found. None of these three species appear above the upper boundary of the Tenuicostatum Zone (Figs. 2,3). In the Semicelatum biohorizon also appears $B$. nitescens, a possibly older species which shows some similarities with $B$. chakdallaense and persists in the Elegantulum Subzone of the Serpentinum Zone. The specimen of $B$. nitescens figured by Bizon et al. (1966) from the Levantine Sector of the Iberian Range is associated with several brachiopod species that only coexist at levels of the Semicelatum Subzone of the Tenuicostatum Zone (García Joral and Goy, 2000; Baeza-
Carratalá et al., 2016). Other species, like B. ibericum nov. sp. and $B$. tumidum have also been recorded in the upper part of the Tenuicostatum Zone and in the lower part of the Serpentinum Zone. B.? betetensis nov. sp. has been recorded only in the Elegantulum Subzone (Figs. 2,3).

Outside the Iberian Range, the oldest Bouleiceras species should be $B$. chakdallaense, recorded in the middle member of the Datta Formation (probably in the Tenuicostatum Zone) of Northeastern Pakistan, showing remarkable affinities with B. elegans from Madagascar, Arabia and Spain. Bouleiceras cf. chakdallaense has been identified in Chile by Hillebrandt and Schmidt-Effing (1981) at levels corresponding to the Tenuicostatum Zone, Simplex Subzone, which is roughly equivalent in the Sub-Mediterranean Province to the Tenuicostatum Zone, Paltum Subzone, and the lower part of the Semicelatum Subzone (Page, 2003). In the same member of the Datta Fm. of Northeastern Pakistan is also recorded $B$. nitescens, a species also bituberculated in the internal whorls. The first record of this species in Madagascar and Arabia is imprecise but it is probably located in the Semicelatum Subzone of the Tenuicostatum Zone. In Portugal, the specimens figured by Mouterde (1953) as Bouleiceras cf. nitescens and Bouleiceras sp. from Ribeiro da Povoa (South of Coimbra) and by Mouterde and Rocha (1981) as Bouleiceras nitescens? from the Couros river area (North of Tomar), are associated to Hildaites and attributed to the lower part of the Levisoni Zone (equal to Serpentinum Zone of the NW European province). However, in the case of the Ribeiro da Póvoa specimens, it cannot be discarded that they come from the 


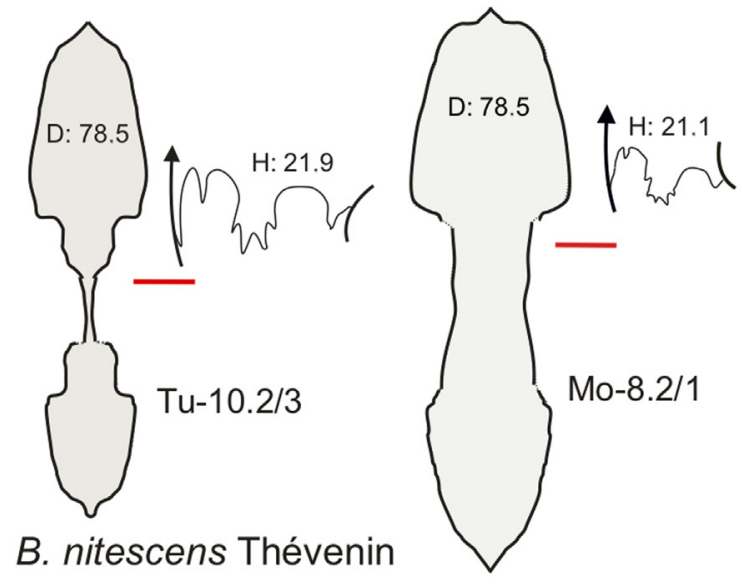

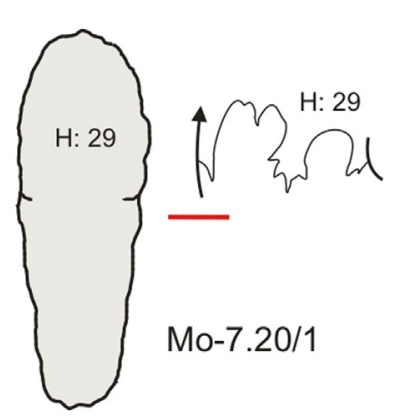

B. tumidum Arkell

B. elegans Arkell

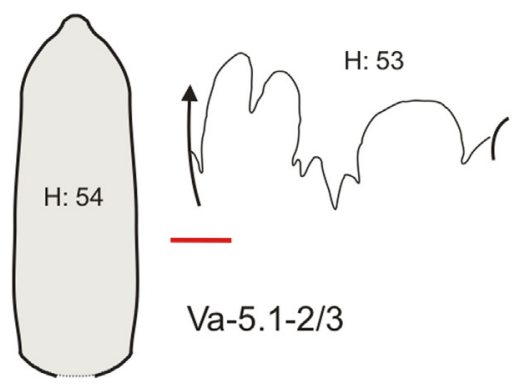

B.? betetensis nov. sp.

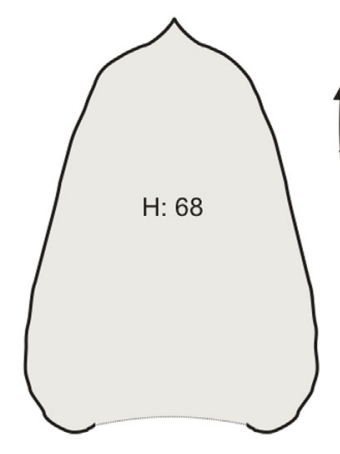

Tu-10.2/1

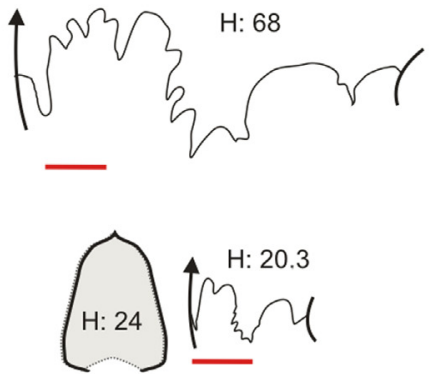

Mo-5-2/6

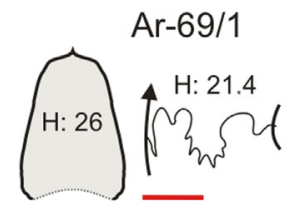

B. arabicum Arkell

Mo-7.20/2

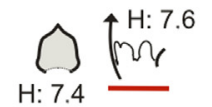

\section{B. marraticum Arkell}

\section{B. ibericum nov. sp.}

Fig. 9. Sections and suture lines of the Bouleiceras species studied. Scale bars: $1 \mathrm{~cm}$.

uppermost part of the Polymorphum Zone (equivalent to the Tenuicostatum Zone of the NW European province) since they are also associated with Protogrammoceras madagascariense and the brachiopod Calyptoria vulgata (Cooper, 1989), which rarely exceed the boundary between the Polymorphum and Levisoni Zones.

Among the other species described by Arkell (1952) in Arabia, $B$. arabicum has been recorded also in Kenya (Ayer, 1952; Arkell, 1952 ) and the Iberian Range; B. marraticum is only known in its type locality and in the Iberian Range, where it does not reach the boundary between the Tenuicostatum and Serpentinum zones; and $B$. rectum has been cited from Madagascar, Arabia (Arkell, 1952) and Somalia (Chiocchini et al., 2002), supposedly in the Serpentinum Zone, although its association with "Spiriferina madagascariensis" (= Calyptoria sp.) in Somalia probably means that it may be present in the uppermost Tenuicostatum Zone. Other species such as $B$. tumidum and B. ibericum nov. sp. (Madagascar and Iberian Range) are recorded in the upper part of the Tenuicostatum/Polymorphum Zone and in the lower part of the Serpentinum/Levisoni Zone. Faugères (1975) cited Bouleiceras aff. arabicum Arkell from Jbel Dehar in N'Sour (Morocco) from $60 \mathrm{~m}$ below the lower boundary of the Bifrons Zone, as well as "Bouleiceras associated to Hildaites or to Harpoceratoides and Hildaites", assigned to the Serpentinum Zone. In Chile, apart from $B$. cf. chakdallaense, another species Bouleiceras chilense Hillebrandt, 1973 has been described from the Hoelderi Zone, equivalent to the Falciferum/Serpentinum Zone of Western Tethys (Hillebrandt and Schmidt-Effing, 1981). This species shows a remarkable similarity with $B$. elegans for its similar ontogenetic development. Finally,? B. betetensis nov. sp., with umbilicus and section very close to those of Nejdia and suture line as in Bouleiceras, is among the species with a later record in the Elegantulum Subzone. It is only known from the
Iberian Range and its stratigraphic position is almost equal to the one shown by $B$. chilense in the Andean region.

The record of Bouleiceras seems to be limited to the Tenuicostatum/Polymorphum Zone and the lower part of the Serpentinum/Levisoni Zone. The genus first occurred in the lower part of the Tenuicostatum Zone in Chile and probably Pakistan, and from the Semicelatum Subzone upwards in Arabia, Northeastern and Northwestern Africa, and the Iberian Peninsula. Apparently, no species has been found above the Elegantulum Subzone. The stratigraphical distributions of all Bouleiceras species described in this paper are shown in Fig. 10, either directly from the published data or inferred as previously discussed.

\section{Evolution and dispersal of Bouleiceras}

According to Guex (1974), the origin of the genus Bouleiceras should be sought in the Hildocerataceae of the latest Pliensbachian showing periumbilical tubercles, as in Canavaria Gemmellaro, 1886 and Tauromeniceras Mouterde, 1967, which group evolute, tuberculated, and ribbed forms with simple suture line. This origin is supported by cladistic analysis (Rulleau et al., 2003Bardin et al., 2017). Most likely, it probably derives from some species of Tauromeniceras from the terminal part of the Spinatum Zone, Hawskerense Subzone (equivalent to the Emaciatum Zone, Elisa Subzone in the Mediterranean Province), close to T. elisa (Fucini) or T. nerina (Fucini). Both species show a ventral region provided with a keel flanked by two depressed areas that become into furrows as the growth of the shell progresses. Its ornamentation consists of straight, slightly retroverse ribs, with small tubercles at the umbilical end and - at the last whorl - also thickenings or tubercles near the umbilical edge (Braga, 1983: pp. 308-313, pl. 15, 4-10). 


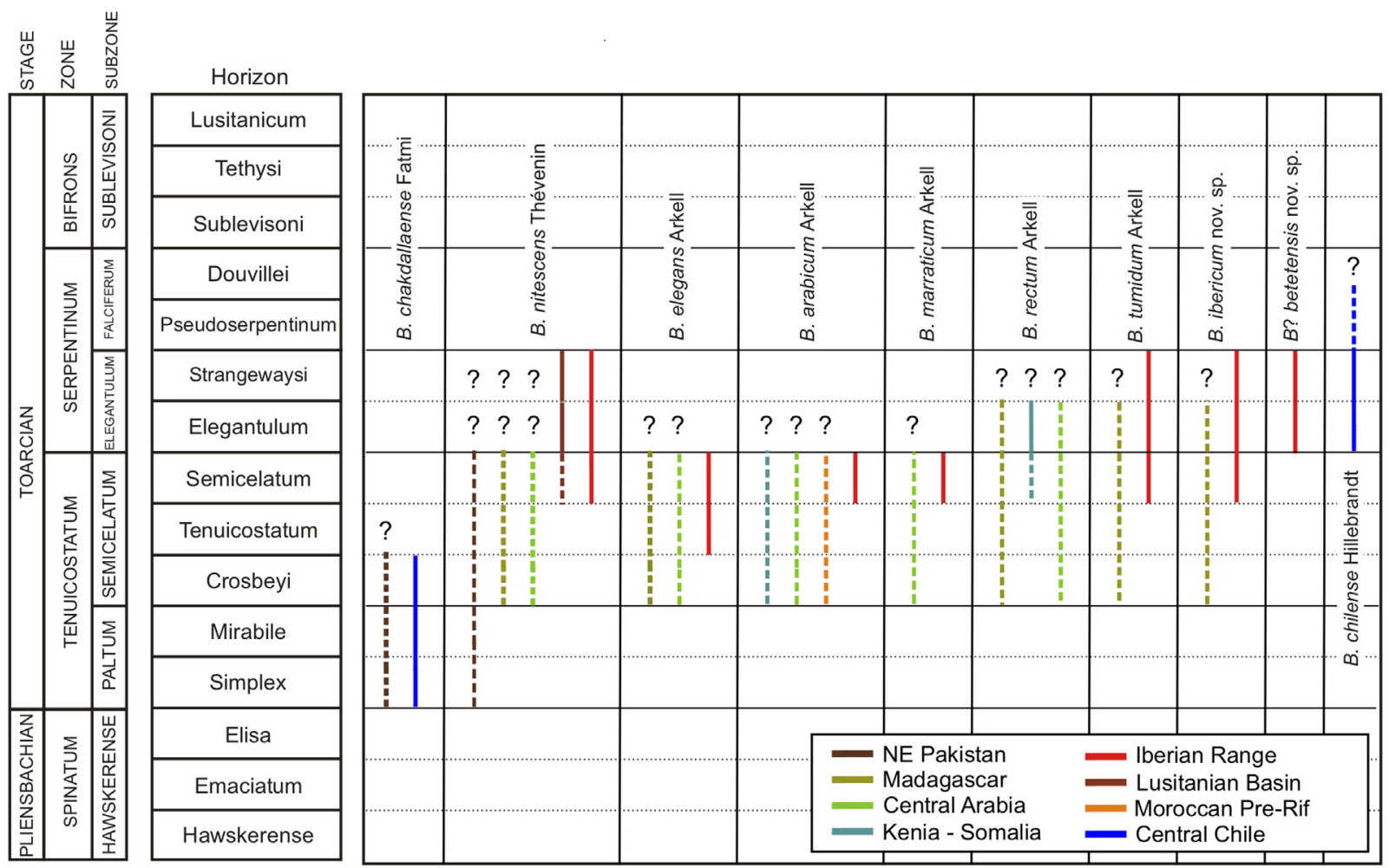

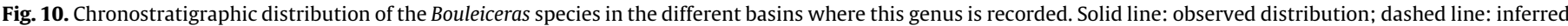
distribution. See the text for more explanations.

These species have been recorded in Southern Europe, including Betics, Iberian Basin, Lusitanian Basin, Sicily and the Apennines (Fucini, 1931; Ferretti, 1967; Mouterde, 1967; Comas Rengifo, 1982; Braga, 1983). The Tauromeniceras-Bouleiceras transition would involve the attenuation of the ornamentation in the external whorls and an increase of involution. The geographical area where this transition took place is not properly known. In the Semicelatum Subbiochron, the paleogeographical distribution and diversity of the genus reach its maximum, being its last records from the early Serpentinum Zone.

Rulleau et al. (2003) point out that the Andean forms of Bouleiceras are small, slightly more precocious, with little relation whit almost all of Malagasy types, and could represent vicariant evolution. Riccardi (1991) on the basis of ammonoids distributions considered that marine connection between Eastern Tethys and South America was in the Lower Jurassic through the Australian margin of Gondwana and, from the Pliensbachian onward, connection with Western Tethys occurred through the sporadically opened "Hispanic Corridor" in Central America. In this sense, the most recent presumed age of $B$. chilense suggests that it could derive from populations of $B$. elegans reaching the Andean Area from the Western Tethys through the Hispanic Corridor (Fig. 11). However, the arrival of primitive forms of the genus from Western Tethys to South America via the Hispanic Corridor in the early Tenuicostatum Zone is more speculative, since these primitive forms (as $B$. chakdallaense) have not been recorded in the Western Tethys. On the other hand, Canavaria and Tauromeniceras are present in the Andean region (Hillebrandt, 2006; Riccardi, 2008).

Ammonoid taxa show often a very wide or cosmopolitan distribution, that implies a high dispersal ability, but the latitudinally restricted distribution of Bouleiceras, between $30{ }^{\circ} \mathrm{N}$ and $30^{\circ} \mathrm{S}$ (Fig. 11) seems to be controlled by temperature constraints. Martínez (2017b) postulated that other genera of the same subfamily (Paroniceras, Frechiella and Oxyparoniceras) have been influenced in their geographical distribution more by latitudinal constraints (temperature) than by bathymetry or other factors. Furthermore, the distribution of Bouleiceras shows a notable parallelism with that of the contemporaneous brachiopod Calyptoria (Cooper 1989), that has been interpreted by BaezaCarratalá et al. (2018) as controlled mainly by temperature. Paleotemperature increased globally in the late Tenuicostatum and the Eaely Serpentinum zones by $7{ }^{\circ} \mathrm{C}$ (Bailey et al., 2003; McElwain et al., 2005; Gómez et al., 2008; Gómez and Goy, 2011, Ruebsam et al., 2019), reaching in wide areas values similar to the equatorial conditions of the Arabian region. This warming is associated with high sea levels (Hallam, 1997; Ruesbam et al., 2019) probably favoring the circulation of big masses of water from the Western Tethys to the Panthalassa trough the Hispanic Corridor. That could have triggered a sort of "suction effect" that would accelerate the westward current in the South of Tethys and the southward current through the Viking Corridor, enhanced at this time as shown by Arias (2007). The effects of this change in currents must have been very strong, not only enabling the dispersal of faunas to the west but also favoring the disruption of provincialism observed in many groups (García Joral and Goy, 2000; Damborenea, 2002; Macchioni and Cecca, 2002; Rulleau et al., 2003; Arias, 2006b; Dera et al., 2010; Andrade et al., 2016).

If the distribution of Bouleiceras was conditioned by water temperature, the Australian Way does not seem very suitable, since currents to the east in medium latitudes would probably be too cold and slow for this purpose, precluding dispersal from the Indo-Madagascan area to South America through Australia (Arias, 2008). New findings of Bouleiceras in the Northern Gondwana paleomargin or other regions will surely be needed to help resolve the issue of the origin and dispersal of this genus. 


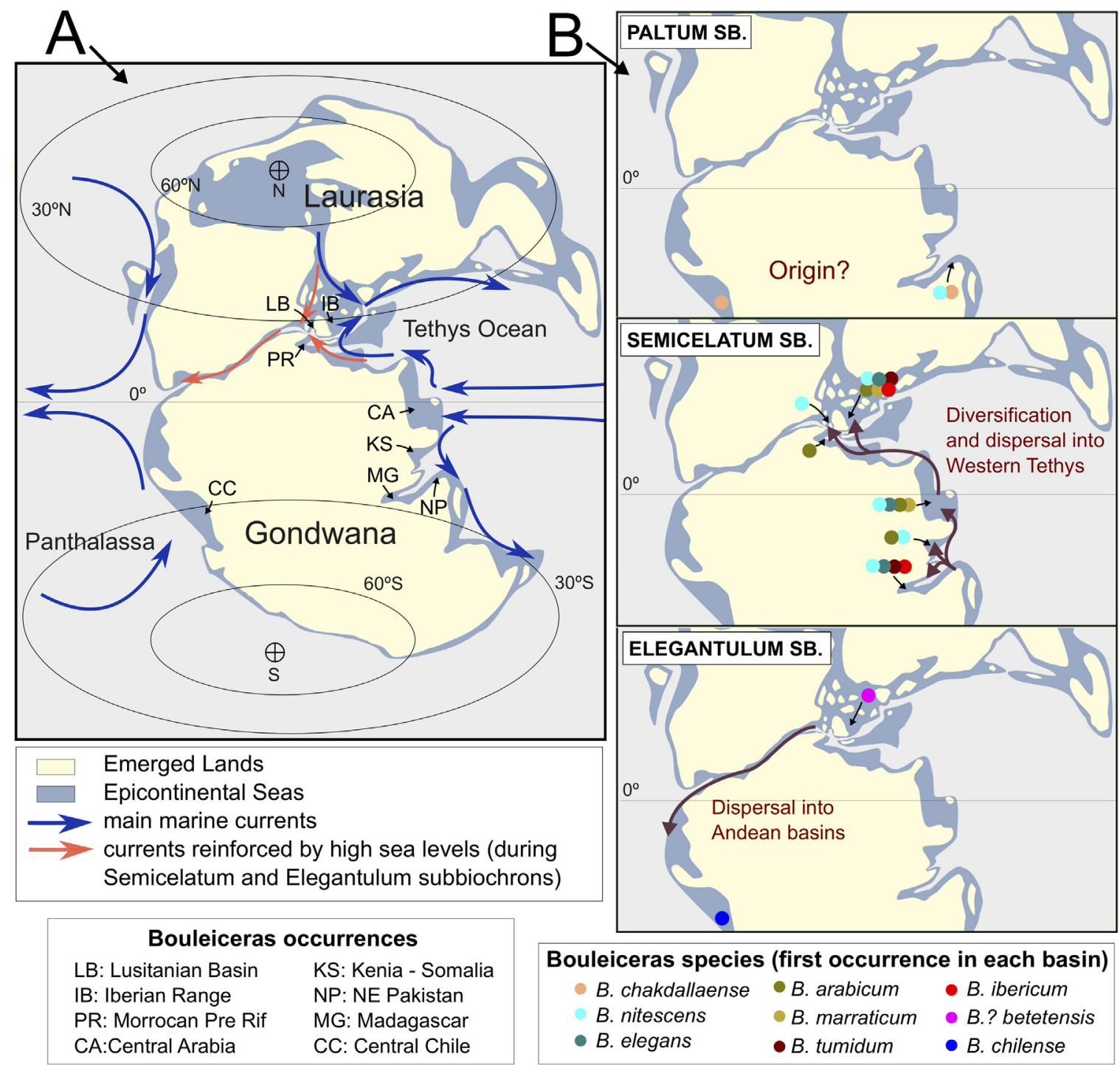

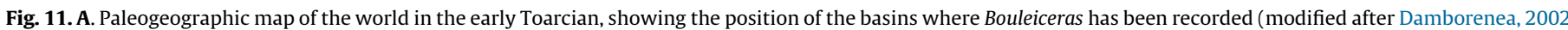

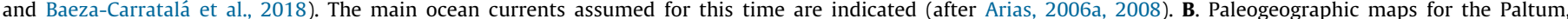

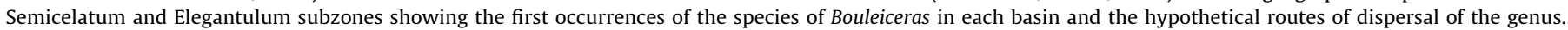

\section{Conclusions}

The systematic revision of the specimens attributed to Bouleiceras from the Iberian Range has led to the recognition of seven species of this genus, including two new taxa: $B$. nitescens Thévenin, B. elegans Arkel, B. arabicum Arkel, B. marraticum Arkel, B. tumidum Arkel, B. ibericum nov. sp., and B.? betetensis nov. sp. All these species come from the Central and Levantine sectors of the basin and have been recorded in the Semicelatum Subzone of the Tenuicostatum Zone and in the Elegantulum Subzone of the Serpentinum Zone. These data, together with the known record of the genus in other regions, make it possible to establish more accurately the stratigraphic distribution of Bouleiceras in the Tenuicostatum Zone and the lower part of the Serpentinum Zone. The genus Bouleiceras probably derives from some species of Tauromeniceras from the Hawskerense Subzone of the Spinatum Zone. From these primitive forms (as B. chakdallaense) would have arisen most of the species of this genus ( $B$. nitescens, $B$. elegans, $B$. arabicum, $B$. marraticum, $B$. tumidum, $B$. ibericum nov. sp.) which dispersed through the northern margin of Gondwana to the
Westernmost Tethys. The most recent presumed age of $B$. chilense suggests that it could have derived from populations of $B$. elegans. Finally, $B$.? betetensis nov. sp. seems to be a transitional species to the genus Nejdia, that is recorded in the Falciferum Subzone of the Serpentinum Zone of the Iberian Range. The area of origin and the dispersal routes of Bouleiceras remain unclear, but their distribution seems to follow high temperature conditions and would have been favored by high sea levels.

\section{Acknowledgments}

We sincerely thank Prof. Antonio Goy for his continuous advices and support in the elaboration of this paper. We also acknowledge the editors G. Escarguel and C. Monnet, Prof. J. Sandoval and an anonymous referee for their valuable comments. This research is a contribution to the IGCP-655 "Toarcian Oceanic Anoxic Event: Impact on marine carbon cycle and ecosystems", and to the Research Group PBM-910431 (Complutense University of Madrid). It was financially supported by the Research Project CGL2015-66604-R (MINECO, Government of Spain). 


\section{References}

Andrade, B., Duarte, L.V., García Joral, F., Goy, A., Henriques, M.H., 2016. Palaeobiogeographic patterns of the brachiopod assemblages of the Iberian Subplate during the Late Toarcian-Early Aalenian (Jurassic). Palaeogeography, Palaeoclimatology, Palaeoecology 442, 12-22.

Arias, C., 2006a. Northern and Southern Hemispheres ostracod palaeobiogeography during the Early Jurassic: possible migration routes. Palaeogeography, Palaeoclimatology, Palaeoecology 233, 63-95.

Arias, C., 2006b. Changes in ostracod provincialismduring the Early Toarcian in the European Sea-Western Tethys area. Revista Española de Micropaleontología 38 245-267.

Arias, C., 2007. Pliensbachian-Toarcian ostracod biogeography in NW Europe: Evidence for water mass structure evolution. Palaeogeography, Palaeoclimatology, Palaeoecology 251, 398-421.

Arias, C., 2008. Palaeoceanography and biogeography in the Early Jurassic Panthalassa and Tethys Oceans. Gondwana Research 14, 306-315.

Arkell, W.J., 1952. Jurassic ammonites from Jebel Tuwaiq, central Arabia. Philosophical Transactions of the Royal Society of London B 236, 241-313.

Arkell, W.J., 1956. Jurassic Geology of the World. Oliver and Boyd, Edinburgh806.

Ayers, F.M., 1952. Geology of the Wajir-Mandera district. Northeast Kenia. Geological Survey Kenya 22, 25 Report.

Baeza-Carratalá, J., García Joral, F., Goy, A., Tent-Manclús, J.E., 2018. Arab-Madagascan brachiopod dispersal along the North-Gondwana paleomargin towards the Western Tethys Ocean during the Early Toarcian (Jurassic). Palaeogeography, Palaeoclimatology, Palaeoecology 490, 252-268.

Baeza-Carratalá, J.F., García Joral, F., Tent-Manclús, J.E., 2016. Lower Jurassic brachiopods from the Ibero-Levantine sector (Iberian range): faunal turnovers and critical bioevents. Journal on Iberian Geology 42, 355-369.

Bailey, T.R., Rosenthal, Y., McArthur, J.M., van de Schootbrugge, B., Thirlwall, M.F., 2003. Paleoceanographic changes of the Late Pliensbachian-Early Toarcian interval: a possible link to the genesis of an Oceanic Anoxic event. Earth and Planetary Science Letters 212, 307-320.

Bardin, J., Rouget, I., Cecca, F., 2017. The phylogeny of Hildoceratidae (Cephalopoda Ammonitida) resolved by an integrated coding scheme of the conch. Cladistics $33,21-40$.

Basse, É., Karpoff, R., 1957. Quelques Mollusques du Toarcien des environs de Shakra (Arabie séoudite). Bulletin de la Société géologique de France 7, 327-339.

Behmel, H., Geyer, O., 1966. Beiträge zur stratigraphie und paläontologie des Jura von Ostspanien III: stratigraphie und fossilführung im Unterjura von Albarracin (prov. de Teruel). Neues Jahrbuch fur Geologie und Paläontologie, Abhandlungen $124,1-62$

Bizon, G., Champetier, Y., Guérin-Franiatte, S., 1966. Présence de Bouleiceras nitescens Thévenin dans l'Est des Cordillères bétiques (prov. de Valence, Espagne). Bulletin de la Société géologique de France 8, 901-904.

Blaison, J., 1968. Affinités, répartition et typologie du genre 'Bouleiceras' Thévenin 1906. Annales scientifiques de l'Université de Besançon (3, géologie) 5, 41-49.

Braga, J.C., 1983. Ammonites del Domerense de la Zona Subbetica (cordilleras Béticas, Sur de España). Ph. D. thesis, Universidad de Granada, Granada (unpubl.).

Chiocchini, M., Fazzuoli, M., Pavia, J., 2002. The Uanei Formation (Toarcian) in the Iscia Baidoa Area, South Western Somalia. In: Martire, L. (Ed.), Abstracts and Program $6^{\text {th }}$ International Symposium on the Jurassic System. Mondello, Sicily 2002, pp. 33-34.

Collignon, M., 1958. Atlas des fossiles caractéristiques de Madagascar. I: Lias Bajocien. Service Géologique de Madagascar, 1-3.

Comas-Rengifo, M.J., 1974. Estudio paleontológico y bioestratigráfico del Jurásico de Ribarredonda (Guadalajara). Tesis de Licenciatura, Universidad Complutense de Madrid (unpubl.).

Comas-Rengifo, M.J., 1982. El Pliensbachiense de la Cordillera Ibérica. Colección Tesis Doctorales, Universidad Complutense de Madrid, 19/85, 591.

Comas-Rengifo, M.J., Arias, C., Gómez, J.J., Goy, A., Herrero, C., Osete, M.L., Palencia A., 2010. A complementary section for the proposed Toarcian (Lower Jurassic) global stratotype: The Almonacid de la Cuba section (Spain). Stratigraphy and Geological Correlation 18, 133-152.

Comas-Rengifo, M.J., Goy, A., Arche, A., Carenas, B., López-Gómez, J., Rodrigo, A. Segura, M., Ureta, S., 2007. El Mesozoico en el sector central de la Cordillera ibérica. In: Díaz-Martínez, E., Rábano, I. (Eds.), 4th European Meeting on the Palaeontology and Stratigraphy of Latin America. Cuadernos del Museo Geominero 8, pp. 435-485.

Damborenea, S.E., 2002. Jurassic Evolution of Southern Hemisphere Marine Palaeobiogeographic Units Based on Benthonic Bivalves. Geobios M.S. 24, 51-77.

Davies, R.G., Gardezi, A.H., 1965. The presence of Bouleiceras in Hazara and its geological implications. Geological Bulletin Panjab University 5, 23-30.

Dera, G., Neige, P., Dommergues, J.-L., Fara, E., Laffont, R., Pellenard, P., 2010. Highresolution dynamics of Early Jurassic marine extinctions: the case of Pliensbachian-Toarcian ammonites (Cephalopoda). Journal of the Geological Society of London 167, 21-33.

Dubar, G., Elmi, S., Mouterde, R., 1970. Remarques sur le Toarcien d'Albarracin (Province de Teruel-Espagne) et sur sa faune de Bouleiceras. Comptes-rendus sommaires de la Société geólogique de France 5, 162-163.

Dubar, G., Mouterde, R., 1953. Découverte d'Ammonites à affinité arabo-malgache (Bouleiceras) dans le Toarcien inférieur du Portugal. Comptes rendus de l'Académie des Sciences, Paris 237, 575-576.

Elmi, S., Rulleau, L., Gabilly, J., Mouterde, R., 1997. Toarcien. In: Cariou, E., Hantzpergue, P. (Eds.), Groupe Français d'Études du Jurassique: Biostratigraphie du
Jurassique ouest-europeen et méditerranéen. Zonation parallèle et distribution des invertébrés et microfossiles. Bulletin du Centre de Recherches Elf Exploration Production 17, pp. 25-36.

Enay, R., Mangold, C., 1994. Première zonation par ammonites du Jurassique d'Arabie Séoudite, une référence pour la province arabique. Geobios 27, $161-174$.

Fatmi, A.N., 1972. Stratigraphy of the Jurassic and Lower Cretaceous rocks and Jurassic ammonites from northern areas of West Pakistan. Bulletin of the British Museum of London 20, 302-375.

Fatmi, A.N., Hölder, H., 1975. A new Lower Jurassic ammonite genus Kohaticeras from the Shinawari Formation, Kohat Tribal Belt, Pakistan. Paläontologische Zeitschrift 49, 35-43.

Faugères, J.C., 1975. Le Toarcien du Jbel Dehar en N'sour (rides prérifaines, Maroc) : précisions biostratigraphiques et remarques paléontologiques sur les ammonites (genre Bouleiceras, Hildaites) de la zone à Serpentinus. Bulletin de la société géologique de France 17, 117-122.

Ferretti, A., 1967. Il limite Domeriano-Toarciano alla Colma di Domaro (Brescia), stratotipo del Domeriano. Rivista Italiana di Paleontologia e Stratigrafia LXXIII (3), $1-741$.

Fucini, A., 1931. Fossili domeriani dei Dintorni di Taormina, part 4. Palaeontographia Italica 31 (103-159), 93-149.

García Joral, F., Goy, A., 2000. Stratigraphic distribution of Toarcian brachiopods from the Iberian Range (Spain) and its relation to depositional sequences. In: Hall, R.L., Smith, P.L. (Eds.),Proceedings of the Fifth International Symposium on the Jurassic System. GeoResearch Forum, 6. Trans Tech Publications, Switzerland, pp. 381-386

Geyer, O.F., 1965. Einige Funde der arabo-madagassischen Ammoniten-Gattung Bouleiceras im Unterjura der Iberischen Halbinsel. Paläontologische Zeitschrift 39, 26-32.

Geyer, O.F., 1971. Zur paliiobathymetrischen Zuverliissigkeit von AmmonoideenFaunen-Spektren. Palaeogeography, Palaeoclimatology, Palaeoecololy 10, 265272

Gómez, J.J., Goy, A., 2000. Definition and organization of limestonemarl cycles in the Toarcian of the Northern and East-Central part of the Iberian Subplate (Spain). Georesearch Forum 6, 301-310.

Gómez, J.J., Goy, A., 2005. Late Triassic and Early Jurassic palaeogeographic evolution and depositional cycles of the Western Tethys Iberian platform system (Eastern Spain). Palaeogeography, Palaeoclimatology, Palaeoecology 222, 7794.

Gómez, J.J., Goy, A., 2011. Warming-driven mass extinction in the Early Toarcian (Early Jurassic) of northern and central Spain. Correlation with other timeequivalent European sections. Palaeogeography, Palaeoclimatology, Palaeoecology 306, 176-195.

Gómez, J.J., Goy, A., Canales, M.L., 2008. Seawater temperature and carbon isotope variations in belemnites linked to mass extinction during the Toarcian (Early Jurassic) in Central and Northern Spain. Comparison with other European sections. Palaeogeography, Palaeoclimatology, Palaeoecololy 258, 28-58.

Goy, A., 1974. El Lías de Rama Castellana de la Cordillera Ibérica. Ph.D. Thesis, Universidad Complutense de Madrid, Madrid (unpubl.).

Goy, A., 1975. Nuevos hallazgos de las faunas Arabo-Malgaches del Toarciense Inferior en la Cordillera Ibérica (España Central). Coloquios de Paleontología 3. 3-9.

Goy, A., Gómez, J.J., Yébenes, A., 1976. El Jurásico de la Rama Castellana de la Cordillera Ibérica (mitad Norte). I. Unidades Litoestratigráficas. Estudios Geológicos 32, 391-423.

Goy, A., Jiménez, A., Martínez, G., Rivas, P., 1988. Difficulties in correlating the Toarcian ammonite succession of the Iberian and Betic Cordilleras. In: Rocha, R.B., Soares, A. (Eds.), 2nd International Symposium on Jurassic Stratigraphie I. Lisboa 1987, pp. 155-178.

Goy, A., Martínez, G., 1990. Biozonación del Toarciense en el sector central de la Cordillera Ibérica. Cuadernos de Geología Ibérica 14, 11-53.

Goy, A., Martínez, G., 1996. Distribución bioestratigráfica de los Bouleiceratinae (Ammonitina) en las cuencas Ibérica y Vasco-Cantábrica. Real Sociedad Española de Historia Natural, Tomo Extraordinario 125 Aniversario 306-310.

Guex, J., 1974. Les Bouleiceratinae Arkell, sous-famille mono ou polyphylétique? Eclogae geologicae Helvetiae 67, 97-129.

Hallam, A., 1997. Estimates of the amount and rate of sea-level changes across the Rhaetian-Hettangian and Pliensbachian-Toarcian boundaries (latest Triassic to early Jurassic). Journal of the Geological Society of London 154, 773-779.

Haug, E., 1910. Traité de Géologie. II. Les périodes géologiques. In: Fascicule 2. Système jurassique et période crétacée. Armand Colin, Paris929-1396.

Herrero Matesanz, C., 1995. Los foraminiferos del Toarciense de la Cordillera Ibérica. Colección Tesis Doctorales, Universidad Complutense de Madrid, 87/93, 524

Herrero-Organero, N., 1986. Lias y Dogger inferior en la Region de Moyuela Muniesa (Teruel). Tesis de Licenciatura, Universidad Complutense de Madrid, 108

Hillebrandt, A. von, 1973. Die ammonitengattungen Bouleiceras und Frechiella im Jura von Chile und Argentinien. Eclogae geologicae Helvetiae 66, 351-363.

Hillebrandt, A. von, 1984. The faunal relations of the Lower Jurassic ammonites of South America. In: Michelsen, O., Zeiss, A. (Eds.), International Symposium on Jurassic Stratigraphy 2. Erlangen, pp. 715-729.

Hillebrandt, A. von, 1987. Liassic ammonite zones of South America and correlations with others provinces. In: Volkheimer, W. (Ed.), Bioestratigrafía de los Sistemas regionales del Jurásico y Cretácico en América del Sur 1. Mendoza, pp. 111-157.

Hillebrandt, A. von, 2006. Ammoniten aus dem Pliensbachium (Carixium und Domerium) von Südamerika. Revue de Paléobiologie 25, 1-403. 
G Model

GEOBIO-918; No. of Pages 14

14

G. Martínez, F. García Joral/Geobios xxx (2020) xxx-xxx

Hillebrandt, A. von, Schmidt-Effing, R., 1981. Ammonites aus dem Toarcium (Jura) von Chile (Sudamerika). Zitteliana 6, 3-74.

Howarth, M.K., 2013. Part L, Revised, Volume 3B, Chapter 4: Psiloceratoidea, Eodoceratoidea, Hildoceratoidea. -- Treatise Online Number 57. 1-139, Lawrence, Kansas.

Korn, D., 2010. A key for the description of Palaeozoic ammonoids. Fossil Record 13, $5-12$.

Macchioni, F., Cecca, F., 2002. Biodiversity and biogeography of middle-late Liassic ammonoids: implications for the Early Toarcian mass extinction. Geobios M.S. $24,165-175$.

Marin, Ph., Toulouse, D., 1972. Le Lias du Nord de la Province de Teruel (Espagne) : précisions d'ordre chronostratigraphique. Comptes rendus de l'Académie des Sciences de Paris 274, 3356-3358.

Martínez, G., 2017a. Nuevos datos taxonómicos del género Bouleiceras Thévenin (Ammonoidea) en la Cordillera Ibérica (España). In: O’Dogherty, L. (Ed.), Libro de resúmenes 33 Jornadas de Paleontología. Sociedad Española de Paleontología, Cádiz, 2017, pp. 113-114.

Martínez, G., 2017b. Paroniceras, Frechiella y Oxyparoniceras (Ammonitida) en relación con las fluctuaciones térmicas y los ciclos transgresivo-regresivos detectados en el Toarciense de España. Spanish Journal of Palaeontology 32, 109-114.

McElwain, J.C., Wade-Murphy, J., Hesselbo, S.P., 2005. Changes in carbon dioxide during an oceanic anoxic event linked to intrusion into Gondwana coals. Nature 435, 479-482.

Mouterde, R., 1953. Une forme d'affinités arabomalgaches, Bouleiceras, dans le Toarcien inférieur de Coimbra. Boletim da Sociedade Geologica de Portugal $11,93-99$.

Mouterde, R., 1967. Le Lias de Portugal. Vue d'ensemble et division en Zones. Comunicaçoes dos Serviços Géologicos de Portugal 52, 209-226.
Mouterde, R., 1970. Age toarcien et répartition du genre Bouleiceras dans la péninsule ibérique. Comptes rendus sommaires des séances de la Société géologique de France 5, 163-164.

Mouterde, R., 1971. Une coupe du Lias à Obón aux confins des provinces de Teruel et Saragosse. Cuadernos de Geología Ibérica 2, 345-354.

Mouterde, R., Rocha, R.B., 1981. Le Lias de la région de Rio de Couros (Portugal). Boletim da Sociedade Geologica de Portugal 22, 209-220.

Osete, M.L., Gialanella, P., Gómez, J.J., Villalaín, J.J., Goy, A., Friedrich, H., 2007. Magnetostratigraphy of Early-Middle Toarcian expanded sections from the Iberian Range (central Spain). Earth and Planetary Science Letters 259, 319-332.

Page, K.N., 2003. The Lower Jurassic of Europe: its subdivision and correlation. Geological Survey Denmark and Greenland Bulletin 1, 23-59.

Riccardi, A.C., 1991. Jurassic and Cretaceous marine connections between the Southeast Pacific and Tethys. Palaeogeography, Palaeoclimatology, Palaeoecology $87,155-189$.

Riccardi, A., 2008. The marine Jurassic of Argentina: A biostratigraphic framework. Episodes 31, 326-335.

Ruebsam, W., Mayer, B., Schwark, L., 2019. Cryosphere carbon dynamics control early Toarcian global warming and sea level evolution. Global and Planetary Change 172, 440-453.

Rulleau, L., Bécaud, M., Neige, P., 2003. Les ammonites traditionnellement regroupées dans la sous-famille des Bouleiceratinae (Hildoceratidae, Toarcien) : aspects phylogénétiques, biogéographiques et systématiques. Geobios 36, 317-348.

Steinecke, M., Bramkamp, R.A., 1952. Mesozoic rocks of eastern Saudi Arabia. American Association of Petroleum Geologists Bulletin 36, 909.

Thévenin, A., 1906. Sur un genre d'ammonites du Lias de Madagascar. Bulletin de la Société géologique de France 6, 171-173.

Thévenin, A., 1908. Paléontologie de Madagascar, 5: fossiles liasiques. Annales de Paléontologie 3, 1-39.

Please cite this article in press as: Martínez, G., García Joral, F., Bouleiceras (Hildoceratidae, Ammonitina) from the lower Toarcian (Jurassic) of the Iberian Range (Spain): Taxonomy, stratigraphic distribution and insights on its dispersal. Geobios (2020), https:// doi.org/10.1016/j.geobios.2020.07.001 